\title{
Performance Evaluation of Drip System of Irrigation for Brinjal Crop
}

\author{
Subarna Ghosh ${ }^{1 *}$, Yograj Dewangan ${ }^{1}$, Arjun Choudhary ${ }^{1}$, \\ Anup Kumar Pandey ${ }^{1}$ and Vinay Kumar Pandey ${ }^{2}$ \\ ${ }^{1}$ College of Agricultural Engineering, Bapatla522101, India \\ ${ }^{2}$ Swami Vivekanand College of Agricultural Engineering and Technology, Raipur 492001 \\ ${ }^{3}$ B.R.S.M. College of Agricultural Engineering and Technology and Research Station, \\ Mungeli 495334, India \\ *Corresponding author
}

\section{A B S T R A C T}

\section{Keywords}

Inline drippers,

Uniformity

coefficient

Article Info

Accepted:

05 February 2020

Available Online:

10 March 2020
Drip system of irrigation provides enhanced water use efficiency and water application efficiency up to $90 \%$ whereas it is about $70 \%$ for sprinklers and $45 \%$ for flood method of irrigation. In this method as water is supplied directly to crop root zone through drippers, water losses in distribution and conveyance are far lower than those under flood irrigation. A case study was conducted regarding performance evaluation of drip irrigation system used for growing brinjal in the village Shivpur, district Mungeli in Chhattisgarh. The study was conducted in 50 ha area of farmer's field, irrigated with drip irrigation. The emitter discharge was found to be 0.85 lph. The number of emitters installed in brinjal field in 1 ha area was 90 . In all 5 pumps were supplying water to different crops, out of which 4 were electric operated, each of $3 \mathrm{hp}$ whereas one pump of $5 \mathrm{hp}$ was operated with solar power. On an average the uniformity coefficient of surface and subsurface drip irrigation system for brinjal was found to be $83.6 \%$ and $73.2 \%$ respectively. The plugged emitters in sub surface drip irrigation were the main causes of lower uniformity coefficient.

\section{Introduction}

Drip system of irrigation has been found to be one of the most efficient irrigation systems for the production of vegetables as well as orchard crops. In this system water is applied nearly at the root zone of the plant at frequent intervals for a long period of time. Drip irrigation can potentially provide high application efficiency and achieve high application uniformity. Both are important in producing uniformly high crop yields and preserving water quality. Subsurface drip irrigation offers advantages of less 
evaporation loss and less interference with intercultural operations. However as most system components are located below the soil tillage zone it is difficult to monitor system operations.

In Chhattisgarh region about $30 \%$ of net cropped area was under irrigation in 2011-12 whereas the average national irrigation was about $40 \%$. The irrigation is characterized by a high order variability ranging from $0 \%$ in Dantewada to $82 \%$ in Raipur.

In the existing scheme of micro-irrigation running under the state, the brief about the micro-irrigation system viz. drip and sprinkler systems of irrigation at the fields of beneficiaries since 2005-06 to 2012-13 are 11693 ha and 146317 ha through drip and sprinkler respectively (Das et al., 2016).

Brinjal is a warm crop. A daily mean temperature of $13-21^{0} \mathrm{C}$ is most favourable for its successful production. The soil $\mathrm{pH}$ should not be higher than 5.5 to 6.0 for its better growth and development. Timely irrigation is quite essential for good growth, flowering, fruit setting and development of fruits. Higher yields may be obtained at optimum moisture level and soil fertility conditions. In plains, irrigation should be applied every $3^{\text {rd }}$ to $4^{\text {th }}$ day during hot weather and every 7 to 12 days during winter. Recommended dose of NPK is 200:150:100 kg/ha (nhb.gov.in/pdf/vegetable/ brinjal/bri011.pdf).

To determine if water and chemicals are applied uniformly, it is necessary to evaluate emitter discharge uniformity and system performance. The objective of the study was to evaluate the performance of drip irrigation system on brinjal crop on the basis of emitter flow rate variations, field emission uniformity, design emission uniformity and irrigation efficiency.

\section{Materials and Methods}

\section{Experimental site and plant material}

The experiment was conducted in a farmer's field, located at Shivpur village, $8 \mathrm{~km}$ away from campus of BRSM CAET \& RS, Mungeli during the period $-10^{\text {th }}$ September 2015 to $2^{\text {nd }}$ January 2016 . The study area was characterized by warm summer and received normal rainfall of $1007.8 \mathrm{~mm}$ from $\mathrm{SW}$ monsoon and $80.1 \mathrm{~mm}$ from NE monsoon. The soil of the experimental site was black cotton soil. The site was ploughed and harrowed and then beds were prepared at a spacing of $1.3 \mathrm{~m}$. One month old planting material of brinjal (variety VNR-212), was transplanted in the field on 31 October 2015 with a row to row spacing of $1.2 \mathrm{~m}$ in an area of 0.8 ha under drip whereas the gross cultivated area was 1 ha.

\section{Drip system description}

Drip system was installed in the farmer's field in 0.8 ha area for growing brinjal crop. The specification of drip irrigation system is given in Table 1.

The water source of the area was deep tube well operated by $3 \mathrm{hp}$ submersible electric pump set, with a discharge in the range of 8 lps. The drip irrigation system was installed with submersible pump, non-return valve, water meter, filters, fertilization equipment and flow control, air pressure release valves, on-and-off valves and pressure gauge. The mains and sub-mains were laid underground, at a depth of $45 \mathrm{~cm}$ to avoid damage due to vehicles and equipments. The main pipe was $75 \mathrm{~mm}$ and sub-main pipe was $63 \mathrm{~mm}$ in diameter. There were 45 lateral lines $15 \mathrm{~mm}$ in each sub-main pipe line. Thus in all 135 laterals were used to irrigate 0.8 ha land. Line source emitters, 100 per lateral with spacing of $0.45 \mathrm{~m}$ were used. 


\section{Measurement of emitter discharge}

The discharge of emitters was measured in different laterals at 10 different locations including nearest, middle and farthest points from the sub-mains. The measurement of discharge of emitters was undertaken by measuring the volumetric flow of water for an hour time and the discharge was expressed in litres per hour (lph).

\section{Estimating uniformity of drip irrigation}

The emission uniformity (EU) on the system is the most important parameter to know the system performance. Emission uniformity can be evaluated by direct measurement of emitter flow rate. The water application uniformity of emitters is influenced by the operating pressure, emitter spacing, land slope, size of pipeline, emitter discharge rate and emitter discharge variability.

The emitter flow variation that is determined from the emitter flow profile of the lateral line considers only the variation caused hydraulically and assumes that there is no emitter flow variation from the manufacturer. In fact, for any emitter in the lateral line, there will be manufacturer's variation that depends on the manufacturer's quality control in production.

\section{Manufacturer's Variation}

The manufacturer's variation is actually caused by the non-uniform production from the manufacturer. If there is no manufacturer's variation, the emitter flow should be identical for each pressure.

$$
\mathrm{C}_{\mathrm{v}}=\frac{\mathrm{s}}{\mathrm{q}_{\mathrm{av}}(1)}
$$

where, $\mathrm{C}_{\mathrm{v}}$ is the manufacturer's coefficient of variation of emitter flows is the standard deviation of emitter flow and $\mathrm{q}_{\mathrm{av}}$ is the mean emitter flow.

\section{Emitter Flow Variation Caused by} Manufacturer's Variation

$\mathrm{q}_{\mathrm{var}}=\frac{\mathrm{q}_{\max }-\mathrm{q}_{\min }}{\mathrm{q}_{\max }}$

where, $\mathrm{q}_{\max }$ is maximum emitter flow, $\mathrm{q}_{\min }$ is minimum emitter flow and $q_{v a r}$ is the emitter flow variation.

It can also be expressed by the manufacturer's coefficient of variation as follows:

$\mathrm{q}_{\mathrm{var}}=\frac{1-2 \mathrm{C}_{\mathrm{v}}}{1+2 \mathrm{C}_{\mathrm{v}}(3)}$

Emitter flow variation contributes to the total emission uniformity (EU) of an irrigation system.

Field emission uniformity

$\mathrm{EU}_{\mathrm{f}}=\frac{\mathrm{q}_{\min }}{\mathrm{q}_{\mathrm{av}}} \times 100$

Where, $\mathrm{q}_{\min }$ is minimum emitter discharge and $\mathrm{q}_{\mathrm{av}}$ is average emitter discharge.

\section{Design emission uniformity}

The design emission uniformity or uniformity coefficient is a measurable index of degree of uniformity for any size emitter operating under given conditions.

Karmeli and Keller (1975) were the first to define an empirical design emission uniformity percentage EU for evaluation of the performance of drip irrigation system. Based on it the following equation is commonly used to estimate the design emission uniformity in drip irrigation systems. 
$E U=100 \times\left[1.0-\frac{1.27 c_{v}}{\sqrt{n}}\right] \times \frac{q_{\min }}{q_{a v}(5)}$

where, EU is design emission uniformity (\%), $\mathrm{n}$ is the number of emitters per plant, $\mathrm{C}_{\mathrm{v}}$ is manufacturer's coefficient of variation, $\mathrm{q}_{\min }$ is minimum emitter discharge rate(lph) and $\mathrm{q}_{\mathrm{av}}$ is average emitter discharge rate(lph).

The commonly recommended ranges in design emission uniformity of line sources emitter on annual or perennial crops are:

a) Land slope less than $2 \%=80 \%$ to $90 \%$

b) Land slope greater than $2 \%=75 \%$ to $85 \%$

The flow rate variations of emitters in laterals with respect to its distances from sub-main pipe i.e. in head, middle and tail end reaches were studied and the results were tabulated and analysed.

\section{Irrigation efficiency}

The overall application efficiency of drip irrigation $\left(\mathrm{E}_{\mathrm{a}}\right)$ is defined by Vermeiren and Gobling (1980)as follows:

$E_{a}=K_{s} \times E U_{(6)}$

where, $K_{\mathrm{s}}$ is the ratio between water stored and that diverted from the field. Table 2 shows values of $\mathrm{K}_{\mathrm{s}}$ for different soil types and $\mathrm{EU}$ is the emission uniformity of drip irrigation system.

\section{Results and Discussion}

\section{Emitter discharges}

The results of the study of emitters flow rate in different reaches of laterals indicated that the overall average flow rate of emitters was approximately $1.0 \mathrm{lph}$. The average flow rate in head reaches was found to be $1.112 \mathrm{lph}$ which was highest (Table 3). The average flow rate in middle reaches was found to be $0.97 \mathrm{lph}$ (Table 4). On the contrary, the average flow rate of emitters located at tail end reaches was found to be $0.9175 \mathrm{lph}$ (Table 5) which was lowest.

\section{Emitter flow rate variation}

Low the emitter flow rate variation better is the performance of the drip irrigation system. The value of emitter flow rate variation calculated was $\mathbf{0 . 2 2 5}$ which was quite satisfactory for smooth and continuous operation of the system.

\section{Manufacturer's coefficient of variation}

The manufacturer's coefficient of variation for the emitter material was obtained as $\mathbf{0 . 0 9}$. This value of $\mathrm{C}_{\mathrm{v}}$ is accepted as good for efficient operation of the system. The recommended ranges for $\mathrm{C}_{\mathrm{v}}$ in line source emitters are given in Table 6.

\section{Field emission uniformity}

The field emission uniformity was calculated to be $90.9 \%$. This shows better water application uniformity by the emitters in the field. It mainly depends upon the system operating pressure, emitter physical properties and their blocking potential.

\section{Design emission uniformity}

The uniformity coefficient as calculated by Eq 5 and Table 7 was found to be $\mathbf{8 0 . 5 \%}$. This value represents efficient drip system of irrigation. The water application uniformity of emitters is influenced by the operating pressure, emitter spacing, land slope, size of the pipeline, emitter discharge rate and emitter discharge variability. The value of EU can be improved by reducing the difference between $\mathrm{q}_{\text {min }}$ and $\mathrm{q}_{\mathrm{av}}$ or by using an emitter with a lower $\mathrm{C}_{\mathrm{v}}$. 
Table.1 Specification of DIS for brinjal crop under study

\begin{tabular}{|l|l|}
\hline Crop & Brinjal \\
\hline Emitter type & inline emitter \\
\hline Row to row distance & $1.3 \mathrm{~m}$ \\
\hline Plant spacing & $0.6 \mathrm{~m}$ \\
\hline Emitter spacing & $0.4 \mathrm{~m}$ \\
\hline No. of laterals per row & 1 \\
\hline Avg. emitter discharge & $1 \mathrm{lph}$ \\
\hline Evaporation equivalent & $5 \mathrm{~mm} /$ day \\
\hline Irrigation cycle & 1 \\
\hline Duration of one operation & $2 \mathrm{~h}$ \\
\hline Gross area & $1 \mathrm{ha}$ \\
\hline Net area & $0.8 \mathrm{ha}$ \\
\hline Water source & Tubewell \\
\hline Water requirement & $700 \mathrm{~mm} /$ day \\
\hline Length of lateral & $45 \mathrm{~m}$ \\
\hline
\end{tabular}

Table.2 Water storage efficiency and types of soil

\begin{tabular}{|c|c|}
\hline Types of soil & Water storage efficiency $\left(\mathbf{K}_{\mathbf{s}}\right)$ \\
\hline & 100 \\
\hline Clay & 95 \\
\hline Mixed silt, clay and loamy & 90 \\
\hline Loamy & 87 \\
\hline Sandy & \\
\hline
\end{tabular}

Table.3 Emitters in laterals close to submain

\begin{tabular}{|c|c|c|}
\hline S.No. & Emitter No. & Discharge (lph) \\
\hline 1 & S1 & 1.162 \\
\hline 2 & S2 & 1.125 \\
\hline 3 & S3 & 1.05 \\
\hline Average (S1-S3) & $\mathbf{1 . 1 1 2}$ \\
\hline
\end{tabular}

Table.4 Emitters in laterals in middle portion

\begin{tabular}{|c|c|c|}
\hline S.No. & Emitter No. & Discharge (lph) \\
\hline 1 & S4 & 0.975 \\
\hline 2 & S5 & 0.96 \\
\hline 3 & S6 & 0.975 \\
\hline \multicolumn{2}{|c|}{ Average (S4-S5) } & $\mathbf{0 . 9 7 0}$ \\
\hline
\end{tabular}


Table.5 Emitters in lateral in tail end

\begin{tabular}{|c|c|c|}
\hline S.No. & Emitter No. & Discharge(lph) \\
\hline 1 & S7 & 0.950 \\
\hline 2 & S8 & 0.920 \\
\hline 3 & S9 & 0.900 \\
\hline 4 & S10 & 0.900 \\
\hline \multicolumn{2}{|c|}{ Average (S7-S10) } & 0.9175 \\
\hline \multicolumn{2}{|c|}{ Overall Average (S1-S10) } & $\mathrm{q}_{\mathrm{av}}=1.0$ \\
\hline
\end{tabular}

Table.6 Recommended values of $\mathrm{Cv}$

\begin{tabular}{|c|c|c|}
\hline S.No. & Value of $\mathbf{C}_{\mathbf{v}}$ & Interpretation \\
\hline $\mathbf{1}$ & Less than 0.10 & Good \\
\hline $\mathbf{2}$ & $0.10-0.20$ & Average \\
\hline $\mathbf{3}$ & More than 0.2 & Marginal to unacceptable \\
\hline \multicolumn{2}{|c|}{ Source: A.M. Michael } \\
\hline
\end{tabular}

Table.7 Uniformity coefficient

\begin{tabular}{|c|c|c|c|}
\hline S.No. & Emitter No. & Discharge (lph) & Deviation \\
\hline 1 & S1 & 0.95 & 0.04 \\
\hline 2 & S2 & 0.9 & 0.09 \\
\hline 3 & S3 & 0.92 & 0.07 \\
\hline 4 & S4 & 0.975 & 0.075 \\
\hline 5 & S5 & 0.96 & 0.03 \\
\hline 6 & S6 & 0.975 & 0.015 \\
\hline 7 & S7 & 0.9 & 0.09 \\
\hline 8 & S8 & 1.125 & 0.135 \\
\hline 9 & S9 & 1.162 & 0.172 \\
\hline 10 & S10 & 1.05 & 0.06 \\
\hline Mean & & 0.9917 & 0.717 \\
\hline
\end{tabular}

\section{Irrigation efficiency}

As the soil of the study plot was clay loam type, so the value of $\mathrm{K}_{\mathrm{s}}$ was assumed to be 95 . Thus, the irrigation efficiency was calculated as $76.5 \%$.

In conclusions, the average flow rates of emitters were $1.112 \mathrm{lph}, 0.97 \mathrm{lph}$ and 0.9175 lph at the head end, middle and tail end respectively. The flow rate was higher than the overall discharge by $11.2 \%$ at head end, less than the overall discharge by $3 \%$ and $8.25 \%$ at the middle and tail end respectively which were well within the prescribed limit of $15 \%$. The value of emitter flow rate variation calculated was 0.225 which was quite satisfactory for smooth and continuous 
operation of the system. The manufacturer's coefficient of variation for the emitter material was obtained as 0.09 which shows that the construction materials and design of emitters are good. Field emission uniformity of $90.9 \%$ shows better water application uniformity by the emitters in the field. The design emission uniformity as expressed by formula given by Karmelli and Keller was estimated as $80.5 \%$ which was due to the ageing of pipelines resulting in clogging of pipes as well as emitters. The irrigation efficiency was found to be $76.5 \%$. Irrigation efficiency in this case was less because of less maintenance of the drip system.

\section{References}

Babikar, A. andKhalifa, A. 2006.Comparison of surface and drip irrigation regimes for banana (Musa AAA) cv. Grand Nain in Gezira, Sudan. B.Sc. (Honours) thesis, University of Khartoum, Sudan.

Das, S., Bharathi, K. and Singh, H.S. 2016.Nutritional and sociodemographic profile among Gond tribe of Binouri village, Bilaspur Chhattisgarh (India).Indian Journal of Research in Anthropology.2 (2): 115120.

Michael, A.M. 2008.Irrigation - Theory and Practice. $2^{\text {nd }}$ ed., Vikas Publishing House Pvt. Ltd, New Delhi, 645-648 pp.

\section{How to cite this article:}

Subarna Ghosh, Yograj Dewangan, Arjun Choudhary, Anup Kumar Pandey and Vinay Kumar Pandey. 2020. Performance Evaluation of Drip System of Irrigation for Brinjal Crop. Int.J.Curr.Microbiol.App.Sci. 9(03): 1205-1211. doi: https://doi.org/10.20546/ijcmas.2020.903.141 